\title{
William Harvey's Anatomy Book and Literary Culture
}

\section{MARJORIE O'ROURKE BOYLE*}

Ora et labora: the Benedictine motto unfurls on the banderole of the title-page of William Harvey's masterful Exercitatio anatomica de motu cordis et sanguinis in animalibus (1628). ${ }^{1}$ This monastic motto, "Pray and work", seems an odd advertisement for an anatomy book. Harvey submitted his manuscript for publication to William Fitzer in Frankfurt, who commissioned it to one of the eight printers licensed by the Frankfurter Rat, "mediocre craftsmen" all. The sorry product was a limited edition marred by typographical errors, usually blamed on Harvey's notoriously bad handwriting, an "atrocious, crabbed hand", which necessitated the later printing of errata. De motu cordis et sanguinis has been judged "a rather badly produced book", with most extant copies on thin paper in ordinary type. ${ }^{2}$ It has been supposed that to compensate for the brevity of the seemingly unimportant book its publisher provided "a handsome title-page". 3 But its title-page is homely in comparison with Fitzer's lavish title-pages for Harvey's colleague Robert Fludd, whose Pulsus, the second part of his Medicina catholica, was the first printed agreement with Harvey's theory of the circulation of the blood. Or, consider the impressive volume from Fitzer for Harvey's rival André Du Laurens, Opera omnia anatomica et medica, which Harvey cites a year later in his own modest book. This large volume features Du Laurens's engraved portrait in a medallion flanked by two écorchés. ${ }^{4}$ In physical comparison, Harvey's book recalls the biblical example of David and Goliath or the Renaissance topic of "the fly to the elephant". 5

Whether Fitzer's authors designed or commissioned their title-pages is unrecorded, but they seem individual to each book. ${ }^{6}$ The element on Harvey's title-page that may have been his publisher's choice is the shield. Fitzer had published in the previous year Proscenium vitae humanae, an emblem book with twenty-eight engravings of armorial shields by Virgil Solis, which his predecessor in the printing business, Johann Theodor de Bry, had used. ${ }^{7}$

(C) Marjorie O'Rourke Boyle 2008

* Marjorie O'Rourke Boyle, MA, PhD, is an independent scholar, residing at 95 Normandy Boulevard, Toronto, Ontario, Canada M4L 3K4.

${ }^{1}$ William Harvey, Exercitatio anatomica de motu cordis et sanguinis in animalibus, facsimile rpt. of Frankfurt, William Fitzer, 1628, Birmingham, AL, Classics of Medicine Library, 1978, title-page.

${ }^{2}$ E Weil, 'William Fitzer, the publisher of William Harvey's De motu cordis, 1628', The Library, 1943, 24: 142-64, p. 145.

${ }^{3}$ Geoffrey Keynes, The life of William Harvey, Oxford, Clarendon, 1966, p. 177.

${ }^{4}$ André Du Laurens, Opera omnia anatomica et medica, Frankfurt, William Fitzer, 1627, title-page. See Harvey, op. cit., note 1 above, pp. 19, 21.
${ }^{5} 1$ Sam. 17. For the topic, see Marjorie O'Rourke Boyle, Rhetoric and reform: Erasmus' civil dispute with Luther, Cambridge, MA, Harvard University Press, 1983, pp. 1-4.

${ }^{6}$ In addition to the title-pages of Fludd, DuLaurens, and Harvey discussed here, the following books published by William Fitzer were available for my examination: B G Penot, Tractatus de elementis, 1628, bound with Tractatus varii Vrsellis, 1602, without illustration; Herodian, Historia, translated by Angelo Poliziano, 1627, with a small drawing on the cover; and Daniele Pare, Historia Palatina, 1633, with the motto of the Order of the Garter, "honi soit qui mal y pense", and crowned heraldic devices on the title-page recto, and shields with a crowned lion verso.

${ }^{7}$ See Weil, op. cit., note 2 above, p. 151. 


\section{Marjorie O'Rourke Boyle}

Harvey's title-page does not, however, replicate his own coat of arms as painted on a ceiling in the University of Padua, from which he graduated in arts and medicine: positioned below the word "Anglica", an oval shield bearing an arm with a flaming candle entwined with two serpents. ${ }^{8}$ The graphic design for Harvey's title-page is a cartouche inset with an engraving that allows broad interpretation of the book it introduces, from divine inspiration to a breath of fresh air. A heraldic angel, winged and robed but barefoot on tiptoes as if just landed, is almost central. It stands fashionably in counterposition, head facing left but body twisting right, against a clouded sky and a hilly or mountainous landscape. With its left hand the angel presents a blazoned shield, while its right hand rests on a classical column. The column is Doric, the plainest of the classical orders and by ancient tradition faulty. But it is truncated-minus its proper capital and pedestal—or, by the comparison of architecture and the body, its head and feet. ${ }^{9}$ It compares miserably with the six splendid Corinthian columns that uphold the bustling anatomy theatre on the titlepage of Andreas Vesalius's seminal De humani corporis fabrica ${ }^{10}$ It compares meanly even with the pair of complete Doric columns on the title-page of Francis Bacon's Instauratio magna. These are stylized Pillars of Hercules through which a ship sails adventurously into uncharted scientific waters. ${ }^{11}$ Harvey's lone column is set on uneven, rocky soil, among sparse vegetation. Its architectural order matches the contemporary English usage of the word "Doric" for an unrefined, rustic dialect. ${ }^{12}$ But angel, from the Greek angelos, means "messenger", and the broken column upon which the angel rests its hand delivers message enough: the classical order of medicine is ruined.

This column is wrapped with a banderole inscribed aeterno deo commenda, "commit to eternal God", then, below, the Benedictine motto, Ora et labora, "Pray and work". The angel is not in a prayerful pose, however. The sleeves of its robe are rolled up above both elbows, bareing the lower arms as if ready to work, like an anatomist scrubbed for demonstrations. The higher inscription on the banderole, "commit to eternal God", does display piety. Harvey reports that he was provoked to publish this book by the slander of some fellows in the College of Physicians, London, who enviously accused him of a breach of faith with the universal medical tradition. ${ }^{13}$ Harvey was early practised in prayer for deliverance from enemies. The royal statutes for the King's School, Canterbury, where he studied, required daily prayer morning and evening in the classroom, attendance at the choir offices of matins and vespers on Sundays and feast days, and daily worship at high mass, although that latter interruption of the school day was probably obsolete by Harvey's

\footnotetext{
${ }^{8}$ Reproduced in Ralph H Major, A history of medicine, 2 vols, Springfield, IL, Charles C Thomas, 1964, vol. 1, p. 499.

${ }^{9}$ Harvey, op. cit., note 1 above, title-page. For the classical comparison, see Joseph Rykwert, The dancing column: on order in architecture, Cambridge, MA, MIT Press, 1996, pp. 171-81, 209; for contemporary English understanding of the classical orders, see Eileen Harris with Nicholas Savage, British architectural books and writers, 1556-1785, Cambridge University Press, 1990, pp. 23-31.

${ }^{10}$ Andreas Vesalius, De humani corporis fabrica libri septem, Basel, I Oporini, 1543, title-page.
}

For interpretation, see Andrea Carlino, Books of the body: anatomical ritual and Renaissance learning, trans. John Tedeschi and Anne C Tedeschi, University of Chicago Press, 1999, pp. 8-68.

${ }^{11}$ See A D Burnett, The engraved title-page of Bacon's 'Instauratio magna': an icon and paradigm of science and its wider implications, Durham, Thomas Harriot Seminar, 1998, p. 2 fig. 1, and pp. 6-11.

${ }^{12}$ Oxford English dictionary, second unabridged edition, "Doric", s.v.

${ }^{13}$ Harvey, op. cit., note 1 above, p. 21. 


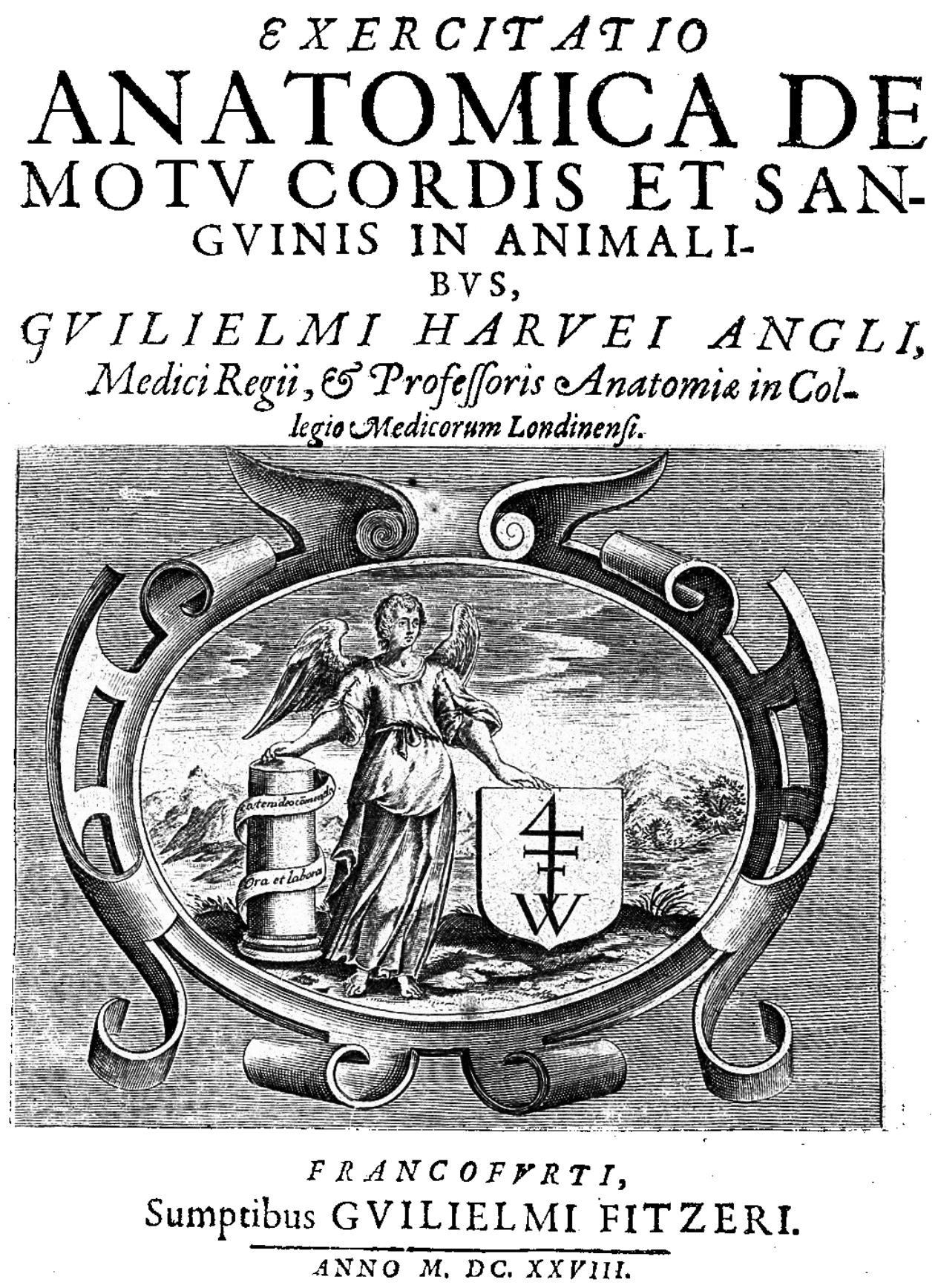

Figure 1: Title-page of William Harvey's Exercitatio anatomica de motu cordis et sanguinis in animalibus, Frankfurt, William Fitzer, 1628. (Wellcome Library, London.) 


\section{Marjorie O'Rourke Boyle}

time. ${ }^{14}$ At scheduled prayer at 6 a.m. young Will learned that God could rightfully be beseeched for victory over one's enemies. The lower master prayed these versicles, and the boys responded alternately:

"O Lord, save the King". "Be unto him, O Lord, a tower of strength".

Respond: "From the face of his enemy".

"Let his enemy have no advantage over him".

Respond: "Nor the son of wickedness approach to hurt him". ${ }^{15}$

Harvey also began each day at the University of Cambridge with compulsory prayer in chapel, ${ }^{16}$ and it was further practice for its students to begin their disputations with a prayer. ${ }^{17}$ Harvey was tutored there by a clergyman, George Estey, whose responsibilities included moral instruction and could extend to catechetical reading and personal prayer. ${ }^{18}$ Despite its secular curriculum in arts, Cambridge was a stronghold of Puritanism and it fostered extracurricular religious education, especially by the statutory requirement of attendance at sermons. ${ }^{19}$ At Gonville and Caius College, Harvey was in a suspicious seat because it was a known haven for papists. Its refounder, John Caius, a prominent president of the College of Physicians, had almost been forced to resign as its head when a search ordered by the vice-chancellor, on advice from the bishop of London, found there "much popish trumpery". His successor in Harvey's day, Thomas Legge, was similarly charged. ${ }^{20}$ During Harvey's study there in 1595 another fellow of that college, William Barret, inflammed the ecclesiastical and academic establishments with a sermon attacking the prime Calvinist doctrine, the certitude of absolute election by divine predestination. The offence provoked an official demand for his public recantation. Then, when Barret's recantation seemed "unreverent, profane, and impudent", almost sixty outraged dons signed a petition blocking his procedure to the bachelor of divinity degree and threatening his expulsion from the university. The theological controversy raged from Lent to November, when Barret finally recanted satisfactorily. It was not a minor incident but an historic occasion because it resulted in the Lambeth Articles, which defined the reformed doctrines for the Church of England. ${ }^{21}$ Thus was Harvey schooled in salvation by orthodoxy and the perils of nonconformity.

\footnotetext{
14 'The refoundation of Canterbury Cathedral and Grammar School, 1541', in Arthur F Leach,

Educational charters and documents 598 to 1909,

Cambridge University Press, 1911, pp. 464, 454, 467, $458,464$.

${ }^{15} \mathrm{C}$ E Woodruff and H J Cape, Schola Regia Cantuariensis: a history of Canterbury School: commonly called the King's School, London, Mitchell, Hughes, and Clarke, 1908, pp. 54-6.

${ }^{16}$ Keynes, op. cit., note 3 above, p. 19.

${ }^{17}$ William F Costello, The scholastic curriculum of early seventeenth-century Cambridge, Cambridge, MA, Harvard University Press, 1958, p. 17.

${ }^{18}$ Keynes, op. cit., note 3 above, p. 11 . Victor Morgan with Christopher Brooke, A history of the University of Cambridge, 4 vols, Cambridge University Press, 1988-2004, vol. 2, pp. 320-33; Mark H Curtis, Oxford and Cambridge in transition,
}

1558-1642: an essay on the changing relations between the English universities and English society, Oxford, Clarendon, 1959, pp. 78-80. See also Erasmus, De recta pronuntiatione, ed. Maria Cytowska, in Opera omnia, Amsterdam, NorthHolland, 1969-, 1-4, p. 30.

${ }^{19}$ Curtis, op. cit., note 18 above, pp. 165-87, 193-4, 197; H C Porter, Reformation and reaction in Tudor Cambridge, Cambridge University Press, 1958, pp. 101-272.

${ }^{20}$ Cited by Curtis, op. cit., note 18 above, p. 168. Brooke in Morgan and Brooke, op. cit., note 18 above, p. 31. For Caius, see also pp. 25-31, 55-78.

${ }^{21}$ Curtis, op. cit., note 18 above, pp. 213-22; Porter, op. cit., note 19 above, pp. 314-15, 344-75. For other theological disputes there in the $1590 \mathrm{~s}$, see Porter, ibid., pp. 277-413; Morgan, in Morgan and Brooke, op. cit., note 18 above, pp. 441-54. 


\section{William Harvey's Anatomy Book and Literary Culture}

Harvey could not have abstracted himself from religion, a motive for multitudes in that age-more than in any other age, it is said — which impressed the daily lives of even the dispassionate. ${ }^{22}$ Beyond baptism, Harvey voluntarily met other ecclesiastical milestones: he was married in church and he signed a will "in the name of the Almighty and Eternal God", rendering his soul to its Maker and Saviour. ${ }^{23}$ Harvey's anatomical writings lack the theological justification that knowledge of the body acknowledges its Creator. ${ }^{24}$ But he believed from his first to his last work in an ultimate principle of life. As the title-page of his Prelectiones anatomie universalis announced in Virgil's pastoral antiphon, "The beginning stands with Jove, o Muses, everything is full of Jove". ${ }^{25}$ Harvey concluded the introduction of these Lumleian lectures in anatomy at the College of Physicians with Augustine's longing for the resurrection of the beauteous body. ${ }^{26}$

The banderole of Harvey's title-page for De motu cordis et sanguinis also displays unconventionally Ora et labora, "Pray and work". This saying, traditionally ascribed to St Benedict's Regula monasteriorum, distils its precepts of a balanced monastic life. Its rationale for manual labour is to counteract spiritual laziness. "Laziness is the enemy of the soul, and therefore the brothers ought to be occupied at certain times in manual labour, alternately at certain hours in divine reading". ${ }^{27}$ Although the motto "Pray and work" is acknowledged theirs by modern Benedictines worldwide and is also attributed in standard reference works to St Benedict, ${ }^{28}$ its historicity has recently been questioned. A survey of early Christian monastic rules agrees that the issue of work versus or with prayer originates in the deliberations and challenges of the desert fathers, where the terms ora and labora are frequently stated in close proximity. It claims, however, that the precise phrase ora et labora does not appear until 1880 in Maur Wolter's Praecipua ordinis monastici elementa et regula s. patris Benedicti. There the abbot of Beuron wrote, "Hence the old and that most renowned watchword of the monks: Pray and Work! The work of God and also

\footnotetext{
${ }^{22}$ Douglas Bush, English literature in the earlier seventeenth century: 1600-1660, 2nd ed. rev., Oxford, Clarendon, 1962, p. 310. See also Ole Peter Grell and Andrew Cunningham (eds), Religio medici: medicine and religion in seventeenth-century England,

Aldershot, Scolar Press, 1996; for Harvey, see Harold Cook, 'Institutional structures and personal belief in the London College of Physicians', in ibid., pp. 91114, p. 102.

${ }^{23}$ Keynes, op. cit., note 3 above, pp. 6, 43, 459.

${ }^{24}$ Roger French, William Harvey's natural philosophy, Cambridge University Press, 1994, pp. 4,70 .

25 "Stat Jove principium, Musae, Jovis omnia plena”. William Harvey, Anatomical lectures: 'Prelectiones anatomie universalis', 'De musculis', ed. Gweneth Whitteridge, Edinburgh, E \& S Livingstone for the Royal College of Physicians, London, 1964, p. 2, citing Virgil, Eclogae 3.60, which begins "Ab Jove". Citation of Jove was fashionable, as in James I's sonnet to 'First Jove, as greatest God above the rest'. James I, 'The twelve sonnets of invocations to the gods', from The essays of a prentise, in the divine art of poesie, Edinburgh, 1584, in Peter
}

C Herman (ed.), Reading monarch's writing: the poetry of Henry VIII, Mary Stuart, Elizabeth I, and James VI, Tempe, Arizona Center for Medieval and Renaissance Studies, 2002, p. 281.

${ }^{26}$ Harvey, Prelectiones anatomie universalis, op. cit., note 25 above, p. 14. Although this edition offers as Harvey's source Augustine, Sermones 243, it seems farfetched that he would have read these sermons. That particular sermon repeats themes of Augustine's much more popular and accessible De civitate Dei at 22.14, which is also closer to Harvey's paraphrase.

27 "Otiositas inimica est animae; et ideo certis temporibus occupari debent fratres in labore manuum, certis iterum horis in lectione divina." Sancti Benedicti regula monasteriorum, Cuthbert Butler (ed), 3rd ed., 3 vols, Freiburg, Herder, 1935, vol. 1, p. 88 .

${ }^{28}$ For example, Jon R Stone, The Routledge dictionary of Latin quotations: the illiterati's guide to Latin maxims, mottoes, proverbs, and sayings, New York, Routledge, 2005, p. 190. 


\section{Marjorie O'Rourke Boyle}

the work of labour, lo a double method of servitude to the Lord, prefigured in Mary and Martha, or the two wings that lift to the highest perfection". ${ }^{29}$

This revisionist historiography is hardly a comprehensive review, however, of everything by or about the Benedictine order since its foundation in the sixth century. And, Wolter's words in fact indicate ora et labora not as his invention but as "old" (vetus), as in the Vetus Testamentum, or Old Testament. He also praises it in the superlative degree as "that most renowned watchword of monks" (clarissimaque illa monachorum tessera: Ora et Labora!). A tessera was a "square" for various purposes, such as mosaics, tessellated pavement, or gaming dice. A square was also given as a token for payment or exchanged in friendship and hospitality. By extension the squared object (tessera) connoted a message. Wolter's usage derives from the Roman military tessera, a small wooden tablet inscribed with the nightly password and a number or mark. This watchword originated with the commander-in-chief and was communicated by the tribune to selected individuals, who handed it on to the entire encampment. Its purpose was to identify and distinguish insiders from outsiders, in military circumstances friends from foes. ${ }^{30}$ This usage was current in Harvey's seventeenth-century England, where a society of adepts was noted by "a peculiar Motto or Tessera wherby they are distinguished". ${ }^{31}$ Exactly a century after Wolter's book, in 1980 the Vatican Library mounted an exhibition in honour of the birth of St Benedict titled 'Ora et labora'. The Benedictine editor of the catalogue declared, "We recognize that the Rule of the founder is easily identified in the famous motto that summarizes in such a perfect manner the programme mapped out by the Rule for those who come to approach God in the silence of the cloister: 'Ora et labora', Pray and work". ${ }^{32}$

The Benedictines were well known in England, still in Harvey's day, as the founders of Western monasticism. As Thomas Hope, who called himself on his own title-page "sometime advocate to King Charles I" wrote, "St Benedict or Bennet, Founder of this Order, was the first who brought the Monastical Life to be esteemed in the West". His community was noted as the source of several other orders that followed his Rule. ${ }^{33}$ William Dugdale's later compilation of 1655, Monasticon anglicanum, believed that Benedict's holy Rule was written in his own hand. ${ }^{34}$ Two disparate borrowings of Ora et labora in Harvey's culture and society deserve notice, however: alchemy and a clan.

\footnotetext{
${ }^{29}$ Marie-Benoît Meeuws, “"Ora et labora”: devise bénédictine?' Collectanea cisterciensia, 1992, 54: 193-219, citing on p. 213: "Hinc vetus clarissimaque illa monachorum tessera: Ora et Labora! Opus Dei atque opus laboris, en duplex Dominici servitii ratio, in Maria ac Martha adumbrata, sive alae duae quae ad altissimam attolunt perfectionem".

${ }^{30}$ tessera, in A Latin dictionary, ed. Charlton T Lewis and Charles Short, s.v.; James Yates, tessera, in A dictionary of Greek and Roman antiquities, ed. William Smith, London, 1848, pp. 112-13; William Ramsay, castra, ibid., p. 251.

${ }^{31}$ See Donald R Dickson, The tessera of Antilia: utopian brotherhoods and secret societies in the early seventeenth century, Leiden, E J Brill, 1998, p. 217.

32 "Tutti si riconoscono nella Regola del fondatore, tutti si identificano facilmente nel celebre
}

motto che riassume in modo così perfetto il programma tracciato dalla Regola a coloro che vengono a cercare Dio nel silenzio del chiostro: 'Ora et labora', prega e lavora". Réginald Grégoire (ed.), XV centenario della nascita di s. Benedetto 480-1980: 'Ora et labora' testimonianze benedettine nella Biblioteca Apostolica Vaticana, Vatican City, Biblioteca Apostolica Vaticana, 1980, p. IX.

${ }^{33}$ Thomas Hope, Practical observations upon divers titles of the law of Scotland, Edinburgh, A Davidson, 1734, p. 434.

${ }^{34}$ William Dugdale, Monasticon anglicanum, 3 vols, London, Richard Hodgkinsonne, 1655, vol. 1, fol. dr. 


\section{William Harvey's Anatomy Book and Literary Culture}

"The motto of the Benedictine monks" is cited as "the alchemist's creed" from its appropriation in 1595 by the Renaissance physician Heinrich Khunrath in his Amphitheatrum sapientiae aeternae. It appears in its epilogue as orandum et laborandum; in oratoriis et laboratoriis; and oratorium, sapienter laboratorium. Marginalia print ora labora, and sive in oratorio, sive in laboratorio. ${ }^{35}$ It is not impossible that Harvey's publisher, Fitzer, intended an esoteric message on the title-page of De motu cordis et sanguinis, for he soon in 1630 and 1631 published many alchemical texts. Among them was a set of eight quarto pamphlets by the alchemist Samuel Norton edited by Edmund Deane, a physician of York. Metamorphosis lapidum was even dedicated to the College of Physicians, London, which included Harvey among its members. ${ }^{36}$ And Fludd, who is credited with introducing Harvey to Fitzer's firm, published with Fitzer his own speculative works, such as Clavis philosophiae et alchymiae Fluddanae. ${ }^{37}$ Yet, there is no philological evidence or even innuendo in Harvey's book of any such esotericism.

There are, however, in Harvey's life and in the lives of his royal Stuart patrons, James I and Charles I, definite Benedictine associations. A clan leads to them by a Scottish backtrack. Ora et labora is the motto of the chief of clan Ramsay. ${ }^{38}$ Such mottoes originated on standards and on armorial seals before they appeared on achievements (coats of arms). ${ }^{39}$ This particular motto dates at least to the seal of William Ramsay, who in 1629 succeeded his father George as second Lord Ramsay of Dalhousie. On a scroll passing behind the crest with a unicorn's head is the motto "ORA ET LABORA". Its supporters of two antelopes segreant ${ }^{40}$ differ from the supporters for William Ramsay's

\footnotetext{
${ }^{35}$ For example, by the Alchemy Museum in Kutna Hora, Czech Republic, which opened in 2002 as the first museum dedicated to alchemy. See: http://www. alchemy.cz/ museum/html. For an introduction to the physician-alchemist Khunrath, see the Department of Special Collections in the Memorial Library of the University of Wisconsin-Madison, which maintains a website: http://www.library.wisc.edu/libraries/ SpecialCollections/khunrath/index.html. Its Duveen Collection has a rare first edition posted online, from which these citations are taken, epilogue (unnumbered page), marginalia on pp. 2, 24. See also Peter Forshaw, "Ora et labora": alchemy, magic and cabala in Heinrich Khunrath's Amphitheatrum sapientiae aeternae (1609)', $\mathrm{PhD}$ thesis, University of London, 2004 , although this was unavailable to me. Cf. the saying in an engraving in the Mutus liber: 'Ora, Lege, Lege, Lege, Relege labora, et Invenies'. Adam McLean, A commentary on the 'Mutus liber', Grand Rapids, MI, Phanes, 1991, pl. 14, and pp. 42, 75. There is an apparent association between alchemy and the Benedictine foundation of Ramsey Abbey, which is discussed below. Manuscripts in the Ashmolean catalogue suggest that its monks engaged in alchemy. MSS. 1415-17 are a translation of a book on the transmution of metals, of which Elias Ashmole notes that "Dr. [John] Dee conceiveth this was written by the Prior of Ramsey". John Wise and W Mackreth Noble, Ramsey Abbey: its rise and fall, taken from the
}

'Ramsey history or chronicle' and other reliable sources; also, an account of the manor \& parish since the 'Dissolution', facsimile rpt. of 1881 ed., Fenstanton, Huntingdon, Grasshopper, 1981 , p. 71.

${ }^{36}$ See Weil, op. cit., note 2, pp. 154, 143-5.

${ }^{37}$ Robert Fludd, Clavis philosophiae et alchymiae Flvddanae, sive, Roberti Flvddi ad epistolam Petri Gassendi ... exercitationem responsem ....,

Frankfurt, William Fitzer, 1633. Accounts of Fludd in the history of medicine need updating from William $\mathrm{H}$ Huffman's research in Robert Fludd and the end of the Renaissance (London, Routledge, 1988). He was not, for example, a Rosicrucian, and it is improbable that such a society ever existed off the page.

${ }^{38}$ I would like to thank Kathleen Gibson, CoDirector of Caven Library, Knox College, University of Toronto, who married into clan Ramsay, for informing me of its motto "Ora et labora", which prompted further research reported here.

${ }^{39}$ Henry Laing, Descriptive catalogue of impressions from ancient Scottish seals, royal, baronial, ecclesiastical, and municipal, embracing a period from A.D. 1094 to the Commonwealth, Edinburgh, The Bannatyne Club, 1850, p. 38.

${ }^{40}$ John Horne Stevenson and Marguerite Wood, Scottish heraldic seals: royal, official, burghal, personal, 3 vols, Glasgow, Robert Maclehose at the University Press, 1940, vol. 3, p. 555. 


\section{Marjorie O'Rourke Boyle}

later achievement in 1633, which are "dexter, a griffin argent; sinister, a greyhound argent, gorged with a collar gules, charged with three escallops of the first" ${ }^{41}$ Thus, the appearance of the motto on William's first seal is earlier. Given the passage of mottoes in the Scottish peerage from father to eldest son, it may well have been passed to him from his father George, whom James I in 1619 created the first Lord Ramsay of Dalhousie (with the precedence of his creation in 1618 as Lord Ramsay of Melrose). This motto, "ORA ET LABORA", continues to the present day from 1633, when Charles I elevated Lord William Ramsay of Dalhousie to first Earl of Dalhousie and Lord Ramsay of Keringtoun. His achievement has a scroll, passing behind its crest of a unicorn's head, which displays dexter ORA ET and sinister LABORA. The blazon is: "Arms: Argent, an eagle displayed sable, beaked and membered gules. Crest: A unicorn's head couped at the neck argent, armed, maned and tufted or. Supporters: Dexter, a griffin with wings displayed ppr.; sinister, a greyhound ppr., gorged with a collar gules, charged with three escallops of the first. Motto: Ora et labora". ${ }^{42}$ The shield with its unicorn crest is carved on a panel above the main, portcullis gateway of Dalhousie Castle, Edinburgh, the historical seat of clan Ramsay. This element of the oldest extant parts of the castle dates to about 1450. The lands themselves were in Ramsay possession, as granted by David I of Scotland to Simundus de Ramseia in the twelfth century and as sworn fealty for "the lands of Dalwolzie" to Edward I in 1296 and 1304 by his descendent, William de Ramsay. ${ }^{43}$

The special gratitude of the Stuart monarchs, whom Harvey attended as physician, to clan Ramsay owes to Sir John Ramsay's reputed rescue in 1600 of James VI of Scotland in the so-called Gowrie conspiracy. As the story goes (not without question), as a favourite page in royal attendance, Ramsay heard the king shout from a window of Gowrie house, "I am murdered! Treason! My lord of Mar, help! help!" Ramsay ran up the back staircase and broke open the door to the chamber to discover Alexander, master of Ruthven, struggling with the king. Drawing his dagger, he plunged it twice into Ruthven's body, while the king hurled his attacker headlong down the stairs. At the bottom Sir Thomas Erskine and Hugh Herries, the king's physician, dispatched him. Then Ramsay

\footnotetext{
${ }^{41}$ Thomas Innes of Learney, Scots heraldry: a practical handbook on the historical principles and modern application of the art and science, 2 nd ed. rev., Edinburgh, Oliver and Boyd, 1956, p. 48.

42 'Dalhousie, chief of Ramsay', in Burke's peerage, baronetage, and knightage, clan chiefs, Scottish feudal barons, ed. Charles Mosley, 107th ed., 3 vols, Wilmington, DE, Burke's Peerage and Gentry, 2003, vol. 2, pp. 1018-19, and the discussion on Scottish mottoes below. I have been unable to discover a record of the achievement of George, first Lord Ramsay. For the diffusion of the motto among the Ramsays, see Royal book of crests of Great Britain and Ireland, Dominion of Canada, India, and Australia derived from the best authorities and family records, 2 vols, Edinburgh, 1883, vol. 2, pp. 332, 115; for its adoption by others, see pp. 7, 206, 310, 363, 410 . The unicorn head on a crest dates on an armorial seal to 1410 and Sir Alexander of Dalhousie, knight.
}

Stevenson and Wood, op. cit., note 40 above, vol. 3, p. 553 .

${ }^{43}$ David Macgibbon and Thomas Ross, The castellated and domestic architecture of Scotland, from the twelfth to the eighteenth century, 5 vols, Edinburgh, David Douglas, 1887, vol. 3, pp. 144-8, see p. 145, fig. 89; Maurice Lindsay, The castles of Scotland, London, Constable, 1986, pp. 181-2. In 1648 the clan castle would be occupied by Oliver Cromwell. The eagle displayed appears for clan Ramsay on seals since the late thirteenth century and in manuscripts on shields since the fifteenth. Laing, op. cit., note 39 above, p. 114; Stevenson and Wood, op. cit., note 40 above, vol. 3, p. 559; R R Stodart, Scottish arms, being a collection of armorial bearings A.D. 1370-1678; reproduced in facsimile from contemporary manuscripts with heraldic and genealogical notes, 2 vols, Edinburgh, W Peterson, 1881, vol. 1, plate 7; vol. 2, pp. 51, 107, 178-9. 


\section{William Harvey's Anatomy Book and Literary Culture}

encountered John, Earl of Gowrie, as he entered his house with servants, and stabbed him through the heart. For this deed Sir John Ramsay was honoured with dignities. With the title Viscount of Haddington he was granted the achievement (coat of arms) of "an arm holding a naked sword and a crown in the middle, with a heart at the point, to impale with his own arms and the motto, Haec dextra videx principis et patriae". He was elected a peer of England in 1620 by the titles Earl of Holdernesse and Baron of Kingston upon Thames. A singular honour was that the day of the rescue, August 5, was proclaimed an annual day of thanksgiving for the king's preservation. Ramsay and his male heirs would in perpetuity on that date bear the sword of state before the king in memory of this deliverance. But Ramsay died childless in 1625 , and his titles became extinct. ${ }^{44}$

Harvey knew this Ramsay lore not just generally as a citizen of the realm or even as a royal physician attendant at court. He knew a Ramsey. Presenting in 1615 a letter from the reputedly heroic Sir John Ramsay to the College of Physicians, London, was Alexander Ramsey, a native of Angus, Scotland, who had earned his MD from Basle. But, because of collegiate objection to patronage, Ramsey had to renounce the letter before admission, which he did earn. He was Harvey's fellow since 1618, a vigilant member of the College, on its records as complaining about a medical theory in 1623 and about the practice of apothecaries in 1633. In the year before the publication of Harvey's book he was variously engaged in a dispute with another fellow and in begging off entertaining fellows at a banquet by plea of impecunity. Ramsey must have been a worthy practitioner because in the College's list of 1635 he is named as a physician to Charles I. ${ }^{45}$ Contrarily, the inimical Earl of Gowrie was in 1600 pronounced guilty of treason and his name and arms were expunged in a public ceremony. A painting of his achievement was ripped in half and hung in the position of shame-upside down - on the Mercat Cross in Edinburgh. The page of the armorial book of Lyon marked the cancellation of the Gowrie assignment from Scotland's heraldic records by a black X through the shield. ${ }^{46}$ This event dramatized the significance of an achievement (coat of arms) in Harvey's society and culture.

Mottoes for heraldic achievements originated in the fourteenth century and were in general use in Harvey's seventeenth century. ${ }^{47}$ They are described as "brief phrases expressing some pious, loyal or moral sentiment, and often playing on the name of the bearer or alluding to the device they accompanied". In Scotland, as distinguished from England, the motto is part of the armorial bearings in the terms of the patent and the subject of grant. It is borne and controlled authoritatively, and changed only by the rematriculation of the arms. It is placed as specified by the blazon, usually above the crest. ${ }^{48}$ In Scotland,

\footnotetext{
${ }^{44}$ William Anderson, The Scottish nation: or the surnames, families, literature, honours, and biographical history of the people of Scotland, 3 vols, Edinburgh, A Fullarton, 1869, vol. 3, p. 322; vol. 2, p. 394.

${ }^{45}$ See William Munk, The roll of the Royal College of Physicians of London: comprising biographical sketches, 2nd ed. rev., 3 vols, London, 1878, vol. 1, pp. 74, 204, 269; Margaret Pelling, with Frances White, Medical conflicts in early modern London: patronage, physicians, and irregular practitioners, 1550-1640,
}

Oxford, Clarendon, 2003, p. 320 and n158, pp. 278, $43 n 54$.

${ }^{46}$ Charles J Burnett and Mark D Dennis, Scotland's heraldic heritage: the lion rejoicing, Edinburgh, The Stationery Office, 1997, p. 13, with illustration.

${ }^{47}$ Stephen Friar (ed.), A new dictionary of heraldry, Sherborne, Alphabooks, 1987, p. 248.

${ }^{48}$ Charles Boutell, Boutell's heraldry, rev. J P Brooke-Little, London, Frederick Warne, 1983, pp. 174-5; Arthur C Fox-Davies, A complete guide to heraldry, rev. J P Brooke-Little, London, Thomas Nelson and Sons, 1969, pp. 341. 


\section{Marjorie O'Rourke Boyle}

distinctly also, the arms must be differenced throughout the family, but the crest may be undifferenced. The crest may serve as a man's badge, the device worn by his household and followers to signify public allegiance to him. Thus, the badge on the clan's cap features the personal crest of the chief within a circular strap and buckle and it usually bears his motto. ${ }^{49}$ The motto was traditionally chosen by the armiger. ${ }^{50}$ Any documentation of why William, second Lord Ramsay, later Earl of Dalhousie, bore "Ora et labora" as his motto was lost to history, much as Harvey's anatomy notebooks perished in a parliamentary raid on Whitehall. ${ }^{51}$ The Lyon Office, which by royal delegation to the chief herald, the Lyon King of Arms, controlled the granting and marshalling of Scottish arms, lost all official records during the Civil War. The Public Register of All Arms and Bearings in Scotland only dates from 1672 by an act of the Scots parliament. ${ }^{52}$

Nevertheless, according to an early authority, a function of heraldry was "to trace the origin of noble and ancient families". ${ }^{53}$ The origin of clan Ramsay had a notable Benedictine association. Its ancestor, Simundus de Ramseia, who received the grant of Scottish land from David I, originated in Huntingdonshire (now Cambridgeshire), England, where David was its Earl. The surname Ramsay derives from its village of Ramsey. ${ }^{54}$ The star of that village, indeed of all Huntingdonshire was a Benedictine foundation, Ramsey Abbey. The boundaries of that county coincided with the abbey's properties, so their histories emerged and developed in tandem. ${ }^{55}$ From its tenth-century foundation the abbey prospered through lavish endowments, which earned it the epithet "Ramsey the rich", to become one of the most important Benedictine houses in England. ${ }^{56}$ The Benedictines there were not cloistered aloof in prayer but broadly and vitally involved in the local society. Ramsey Abbey held vast estates that owed rents of money and goods to be collected, down to the detail for the cellarer of "two fat eels". 57 Its powerful abbot had extensive baronial, franchisal and domanial courts belonging to him or of proprietary

\footnotetext{
${ }^{49}$ Burnett and Dennis, op. cit., note 46 above, p. 32.

${ }^{50}$ Friar (ed.), op. cit., note 47 above, p. 248.

${ }^{51}$ See Keynes, op. cit., note 3 above, pp. 329-30.

${ }^{52}$ Burnett and Dennis, op. cit., note 46 above, pp. $58-59$.

${ }^{53}$ Ibid., pp. 17-18, citing Alexander Nisbet, System of heraldry (1722), preface.

${ }^{54}$ Anderson, op. cit., note 44 above, vol. 3, p. 321. Simundus de Ramseia is recorded as witnessing in 1140 a charter to the monks of Holyrood, a house of canons regular of Augustine that became in 1633 the site of Charles I's coronation, which Harvey probably attended. For Harvey's trip to Scotland, see Keynes, op. cit., note 3 above, pp. 197-8. Note also Keynes's marginal comment that the Great North Road from London to Edinburgh passed through Huntingdon, p. 197, which was the shire of Ramsey Abbey. For Ramsey, see Anne Reiber DeWindt, 'The town of Ramsey: the question of eonomic development, 1290-1523', in Edwin Brezette DeWindt (ed.), The salt of common life: individuality and choice in the medieval town, countryside, and church, Kalamazoo, Medieval Institute Publications of Western Michigan
}

University, 1995, pp. 53-116. See also Ian Blanchard, 'Lothian and beyond: the economy of the "English Empire" of David I', in Richard Britnell and John Hatcher (eds), Progress and problems in medieval England, Cambridge University Press, 1996, pp. 23-45.

${ }^{55} \mathrm{~J}$ Ambrose Raftis, The estates of Ramsey Abbey: a study in economic growth and organization, Toronto, Pontifical Institute of Mediaeval Studies, 1957, pp. 1-2.

${ }^{56}$ Histories are W Dunn Macray, Chronicon Abbatiae Rameseiensis, Rolls Series, 83, London, 1886; rpt. New York, Krauss, 1966, pp. 7-45; Sister Elspeth, 'Abbey of Ramsey', in The Victoria history of the counties of England: Huntingdonshire, 3 vols, rpt. Folkstone, Dawsons of Pall Mall for the University of London Institute of Historical Research, 1974, vol. 1, pp. 377-82.

${ }^{57}$ Raftis, op. cit., note 55 above. See also Edwin Brezette DeWindt, The 'Liber gersumarum' of Ramsey Abbey: a calendar and index of B.L. Harley MS 445, Toronto, Pontifical Institute of Mediaeval Studies, 1976, with citation on p. 365. 


\section{William Harvey's Anatomy Book and Literary Culture}

interest, all three types of English private jurisdiction. ${ }^{58}$ Just before its parliamentary dissolution, canonical visitations reported that the monks were already dissolute in disobeying their Rule-few attended the conventual mass by day or rose by night for matins. Although these latter-day Benedictines were not dedicated in prayer, they were still occupied in labour as agents for the abbey's estates. But the physical decay of the abbey's own buildings portended their political ruin: the roofs were in disrepair, so that rain leaked on the beds of the monks in their dormers and even on the high altar of the church. ${ }^{59}$ At its dissolution Ramsey Abbey and its estates were granted by the Crown in letters patent to Richard Williams alias Cromwell. ${ }^{60}$

From Henry Cromwell, grandfather of the Lord Protector, Oliver, who acquired the site in 1602 and would ultimately rule Charles I's beheading, a future president of the College of Physicians, John Caius, bought ruins of Ramsey Abbey. The purchase is documented as "all that his heap of stone which lyeth in the cross aisle of the Church of the late Abbey being sometime parcel of the said steple or Lantern, before the fall thereof". From this material he had constructed the court of his Caius College in the University of Cambridge. He laid the cornerstone saying, "I dedicate this building to Wisdom. I lay this foundationstone for the furtherance of Virtue and Letters. In the name of the Father and of the Son and of the Holy Ghost". And the achievement granted to his eponymous College affirms sinister "ex prudentia et literis virtutis petra firmatis immortalitas; that is to say, by wisdome and lerning graffed in grace and vertue men come to immortalite". That college court, literally raised from the ruins of Ramsey Abbey, was where the students had their rooms. ${ }^{61}$ Among those students from 1593 to 1597 was William Harvey.

In his epistle dedicatory to De motu cordis et sanguinis Harvey rejected Caius' "wisdome and lerning", as exemplified by his dedicated humanist scholarship on the manuscripts of Galen. ${ }^{62}$ Harvey supplanted it with just as dedicated reasoning from "ocular demonstrations". ${ }^{63}$ As a student living in the court of Caius College, Harvey may have known of the medieval legend about Ramsey Abbey, rumoured throughout England, that the stone walls of its church and cloister "gushed blood drops in a great quantity". ${ }^{64}$ But Harvey was not to discover the secret of the blood's circulation within those reconstructed monastic walls, real or symbolic. Nor would Harvey revert to the monastic tradition of manuscripts. The library holdings of English monasteries were "almost always haphazard" and "preserved through neglect rather than through esteem". ${ }^{65}$ Although continental monasteries conserved some Graeco-Roman medicine,

\footnotetext{
${ }^{58}$ Warren Ortman Ault (ed.), Court rolls of the Abbey of Ramsey and of the Honor of Clare, New Haven, CT, Yale University Press, 1928, pp. ix, lv.

${ }^{59}$ F Donald Logan, 'Ramsey Abbey: the last days and after', in DeWindt (ed.), op. cit., note 54 above, pp. 513-45, on pp. 513-17, 524-7.

${ }^{60}$ Cartularium Monasterii de Rameseia, ed. William H Hart and Ponsonby A Lyons, Rolls Series 79, 3 vols, London, 1884; rpt. New York, Kraus, 1965, vol. 1 , p. vii.

${ }^{61}$ John Venn, Caius College, London, F E Robinson, 1901, pp. 59, 61, 63.
}

\footnotetext{
${ }^{62}$ See Vivian Nutton, John Caius and the manuscripts of Galen, Cambridge, Cambridge Philological Society, 1987. Harvey's relation to Renaissance humanism is documented and analysed at length in manuscripts in process.

63 “... ocularibus demonstrationibus”. Harvey, op. cit., note 1 above, p. 5 .

${ }^{64}$ Macray, op. cit., note 56 above, p. 330.

${ }^{65}$ See David Knowles, Religious orders in England, 3 vols, Cambridge University Press, 1948-59, vol. 2, p. 332.
} 


\section{Marjorie O'Rourke Boyle}

even its traces had all but disappeared in early medieval English houses. Local tradition, herbal therapy, and popular magic prevailed. After the Norman conquest introduced foreigners, however, there were monk-physicians, initially educated in the cloisters, later in the universities. The great houses, such as Ramsey Abbey, concentrated medical books, therapeutic traditions, and the regular need for a physician. But although Benedictine monasteries by the twelfth century boasted of the most able physicians, they did not generally advance the study of medical science. ${ }^{66}$

Harvey's monarch, Charles I, to whom he dedicates De motu cordis et sanguinis, was another intimate of Benedictine ruins. In 1600 he was born in one, the reconstructed former guest house of Scotland's Dunfermline Abbey. After the dissolution of the monasteries Harvey's patron, James I of England, when James VI of Scotland, granted the lordship of Dunfermline to his consort and queen, Anne of Denmark, where she gave birth to Charles. ${ }^{67}$ The Benedictines had been introduced to Scotland in the twelfth century by Queen Margaret, who requisitioned three monks from Canterbury and erected a church and cloister at Dunfermline as the burial place of Scotland's kings. Her son David I, who granted the lands of Dalhousie to Simundus de Ramseia, pre-eminently established and expanded monasticism in Scotland with numerous and varied foundations and endowments. It was he who raised Dunfermline to the dignity of an abbey and introduced to it thirteen more monks from Canterbury. ${ }^{68}$

Since Harvey's book was dedicated to his monarch, Charles I, the Benedictine motto might seem printed riskily in 1628 , almost a century after the parliamentary dissolution of the monasteries. In 1626, parliament, responding to public fears about popery, wrote to the College of Physicians, London, to ensure its compliance with the penal law, enacted after the Gunpowder Plot of assassination. That forbade the practice of medicine by convicted recusants. The letter demanded the names of "those practicing physic and pharmacy in London who were suspected of being papists". The College responded with the names of thirteen physicians and some apothecaries who were known Roman Catholics. No unhappy consequences ensued, however, and the College continued to tolerate Catholic physicians by connivance, since it could not lawfully license them. Nor did the College consistently enforce its own rule against the practice of medicine by clergy. ${ }^{69}$

Although the Benedictines were briefly installed at Westminster Abbey during Mary's reign, after her demise the first expatriate Benedictine to return to England, the novice Mark Barkworth, was executed in 1601, even as he made his full profession of religious vows. Benedictines from the continental missions soon entered England more safely, however. And, although Harvey's patron James I, following the Gunpowder Plot, ordered

\footnotetext{
${ }^{66}$ David Knowles, The monastic order in England: a history of its development from the times of St. Dunstan to the Fourth Lateran Council, 940-1216, 2nd ed., Cambridge University Press, 1963, pp. 516-18.

${ }^{67}$ John G Dunbar, Scottish royal palaces: the architecture of the royal residences during the late medieval and early Renaissance periods, East Linton, East Lothian, Tuckwell, 1999, pp. 87, 88-9.

${ }^{68}$ David Knowles, foreward to Ian B Cowan and David E Easson, Medieval religious houses, Scotland:
}

with an appendix on the houses in the Isle of Man, 2nd ed., London, Longman, 1976, pp. xi-xii. Cowan and Easson, ibid., pp. 5-6; see also pp. 55-62. See also James Moir Webster, Dunfermline Abbey, n.p., Carnegie Dumfermline Trust, 1948.

${ }^{69}$ George N Clark, A M Cook, and Asa Briggs, A history of the Royal College of Physicians of London, 4 vols, Oxford, Clarendon for the Royal College of Physicians, 1964-72, vol. 1, pp. 191-2, 246-7. 


\section{William Harvey's Anatomy Book and Literary Culture}

the Oath of Allegiance to ferret out Catholics, that oath found a strong, if pseudonymous, apologist in the Benedictine Thomas Preston-to the king's delight. Under James's successor, Charles I, the Benedictine David Codner infiltrated his court in the chapel of the king's Catholic wife, Henrietta Maria. There Codner served in the guise of gentleman-inwaiting and art dealer. Yet, even allowing for the Benedictines' royalism, ${ }^{70}$ the reference on Harvey's title-page is more than politically charged. Like the motto itself about the duality of prayer and work, it has further resonances.

As a student at the King's School, Canterbury, Harvey himself prayed and worked amid the ruins and renovations of by far the largest Benedictine foundation in England, the cathedral priory of Christ Church with the Abbey of St Augustine. ${ }^{71}$ Both institutions had amassed from purchases and donors large outstanding libraries with many medical and surgical volumes. These included works of Hippocrates and Galen that Harvey's anatomy intended either to advance or supersede. ${ }^{72}$ The existence of these libraries does not prove their monastic use; Benedictine scholarship is largely unknown and its scant monastic writings are uncreative. The parliamentary dissolution of the priory and abbey at Canterbury did not terminate a vibrant religious and scholarly community but only sealed its moribund state. ${ }^{73}$ The abbey was surrendered to the king by its abbot and half the monks; the tomb of St Augustine, who brought Christianity to England, was destroyed; and the shrine to St Thomas à Becket, murdered for opposing another king, despoiled. The abbot's lodgings were converted into a royal posting house; the abbey church was unroofed and demolished, its stone shipped to Calais for military fortifications or salvaged and sold to local burgesses for building; the library, among the largest in medieval England, was dispersed. Under Harvey's patron James I the renovated lodgings were leased to Sir Edward Wotton and his family. ${ }^{74}$ Beyond Canterbury, at Cambridge, Harvey lived with other students and fellows amid more Benedictine ruins, that court Caius had constructed with stone quarried from Ramsey Abbey. ${ }^{75}$

In Padua, however, Harvey would have encountered Benedictines live and revitalized. The University of Padua, where Harvey studied for degrees in arts and medicine, appointed in his days no Benedictines to its faculty. ${ }^{76}$ But the city housed the most important

\footnotetext{
${ }^{70}$ Without reference to Harvey, see David Lunn, The English Benedictines, 1540-1688: from reformation to revolution, London, Burns and Oates, 1980, pp. 21-49, 90-120, 123.

${ }^{71}$ See Joan Greatrex, 'The cathedral monasteries in the later Middle Ages', in Daniel Rees (ed.), Monks of England: the Benedictines in England from Augustine to the present day, London, SPCK, 1997, pp. $118-34$, on p. 120.

${ }^{72}$ Montague R James, The ancient libraries of Canterbury and Dover, Cambridge University Press, 1903, pp. 55-61, 332-49; Alfred B Emden, Donors of books to S. Augustine's Abbey, Canterbury, Oxford, Oxford Bibliographical Society, Bodleian

Library,1968. See also Sandy Heslop and John Mitchell, 'The arts and learning', in Richard Gem (ed.), English heritage book of St. Augustine's Abbey, Canterbury, London, B T Batsford and English
}

Heritage, 1997, pp. 67-89, on pp. 85-89; Greatrex, op. cit., note 71 above, pp. 128-30, 133.

${ }^{73}$ Greatrex, op. cit., note 71 above, pp. $128-30$, 133,134

${ }^{74} \mathrm{D}$ Sherlock and H Woods, with L Blackmore, et al., in J Geddes (ed.), St. Augustine's Abbey: report on excavations, 1960-78, Maidstone, Kent Archaeological Society for the Historic Buildings and Monuments Commission for England, 1988, pp. 10-13; Margaret Sparks, 'The Abbey site, 1538-1997', in Gem (ed.), op. cit., note 72 above, pp. 143-61, on pp. 143-4.

${ }^{75}$ See Brooke in Morgan and Brooke, op. cit., note 18 above, pp. 25-6.

${ }^{76}$ See Francisco L Maschietto, Benedettini profesori all' Università di Padova (secc. XV-XVIII): profili biografici, Padua, Abbazia di Santa Giustina, 1989. 


\section{Marjorie O'Rourke Boyle}

Benedictine community of all Christendom, in the abbey attached to the church of Santa Giustina. With papal and civic collaboration, Ludovico Barbo had in the fifteenth century zealously rescued the Benedictines from lax observance of their Rule by a rigorous reform of government, piety, and learning. Other houses soon joined the reform, "de Unitate"; when early in the sixteenth century St Benedict's original foundation of Monte Cassino joined, the consolidation became known as the Cassinese Congregation. But already in 1439, a century before the dissolution of the English monasteries, the reformed Benedictine congregation in Padua was the largest and most vibrant Italian monastic community. ${ }^{77}$ Early in the seventeenth century, the English tourist Thomas Coryat, of royal employ, elaborated on Padua's "sumptous and rich" Benedictine monastery of 150 monks and numerous servants. ${ }^{78}$

Harvey could not have missed that massive complex, bulked "a mile in compasse" in the centre of Padua next to the cathedral, one of the largest in the world. The cathedral of Santa Giustina, "a marveilous faire building" as Coryat judged, accrued through the centuries around a late fifth-century oratory to the virgin martyr Giustina. His travelogue identifies her as "a chast and devout Virgin of Padua, who in the time of one of the persecutions of the Primitive Church was cruelly murdered in this City, because she would not worship the Pagan Gods". Coryat notes that her sepulchre commemorates the Christian defeat of the Turks at the Battle of Lepanto in 1571 on her feast day. And he adds that, because of the attribution of this victory to her intercession, silver Venetian coins, giustine, are stamped with her image and engraved Memor ero tui Justina Virgo ${ }^{79}$ St Giustina was commemorated in the main chapel of her cathedral by Paolo Veronese's splendid altarpiece, in which painting she is depicted suffering a martyrdom witnessed by crowds in heaven and on earth. It portrays her traditional iconography of a dagger plunged into her heart through full Renaissance dress. According to the martyrology Giustina continued to pray for an hour while so stabbed. ${ }^{80}$

Beyond its architecture and art, a special feature of her cathedral would have attracted a medical student like Harvey to visit. ${ }^{81}$ Coryat thanks as a guide for his own tour of Padua's

\footnotetext{
${ }^{77}$ Barry Collett, Italian Benedictine scholars and the Reformation: the Congregation of Santa Giustina of Padua, Oxford, Clarendon, 1985, pp. 1-6, 9.

${ }^{78}$ Thomas Coryat, Coryat's crudities, 2 vols, Glasgow, James MacLehose and Sons for the University, 1905, vol. 1, pp. 287, 289-91. Coryat was employed by James I's elder son, Henry, Prince of Wales, who helped him obtain the licence to print this book. It was formally presented to the members of the royal family, including the Duke of York, who became Charles I, the dedicatee of Harvey's book. See Michael Strachan, The life and adventures of Thomas Coryate, Oxford University Press, 1962, pp. 11, 13, 130-2, 134. For the author, see also Anthony Parr, 'Thomas Coryat and the discovery of Europe', Huntington Library Quarterly, 1992, 55: 578-602; Katharine A Craik, 'Reading Coryats Crudities (1611)', Studies in English Literature 1500-1900, 2004, 44: 77-96.

${ }^{79}$ Coryat, op. cit., note 78 above, vol. 1, pp. 288 , 289, 422. See also Ruperto Pepi, 'Cenni storici sulla
}

basilica e sulla badia di santa Giustina', in Paolo Lino Zovatto, et al. (eds), La Basilica di s. Giustina: arte e storia, Castelfranco Veneto, Grifone, 1970, pp. 347 98; Barbara Kilian, S. Giustina in Padua:

Benediktinische Sakralarchitektur zwischen Tradition und Anspruch, Frankfurt, Peter Lang, 1997.

${ }^{80}$ Nicola Ivanoff, 'Sculture e pitture dal quattrocento al settecento', in Zovatto, et al. (eds), op. cit., note 79 above, pp. 270-6, p. 375 pl. 24, p. 407 pl. 85; Terisio Pignatti and Filippo Pedrocco, Veronese, 2 vols, Milan, Electa, 1995, vol. 2, p. 328. See also Andrea Mantegna's polyptych in its chapel of St Luke, which depicts Giustina's heart bleeding in streams on her dress. Alberta de Nicolò Salmazo, Andrea Mantegna, Milan, Rizzoli, 2004, between pp. 40-1 pl. XV, and also pl. 66.

${ }^{81}$ Harvey's conformity to local Catholic culture is attested by the notorial Paduan record for his doctoral degrees that he swore the stipulated oath of papal supremacy. However, it was deliberately omitted at his request from the copy at the Royal College of 


\section{William Harvey's Anatomy Book and Literary Culture}

sites an English gentleman, "Mr. Moore Doctor of Physicke", under whose direction he saw more of the city's sites than he would have found on his own. A physician would have had a particular interest in showing the cathedral, for it houses in a dedicated chapel the reputed bones of St Luke, the evangelist-physician. Renaissance frescoes by Giovanni Storlato narrated the translation and deposition of these remains; the first episode of the cycle depicted Luke clothed as a physician. ${ }^{82}$ Based on a New Testament greeting from "Luke, the beloved physician" (Col. 4:14 Authorized Version), the author of the gospel of Luke and of Acts was traditionally believed to be a physician. The College of Physicians, London, endorsed this tradition. Its seal designed under Caius portrays St Luke in a nimbused doctor's cap seated reading at a lectern. ${ }^{83}$ Among collegiate members in Harvey's time, Fludd declared the biblical basis of his Mosaicall philosophy to be "in imitation of my Physicall and Theo-philosophical Patron St Luke". ${ }^{4}$ The tourist Coryat, son of a rector, also believed Luke's identity as a physician to be the biblical truth. Although the Protestant Reformation spurned the cult of the saints, dismissing Giustina, it exalted the authors of the Bible, revering Luke; so that it was worthwhile, even edifying, for a Protestant to pay a visit to that famous Catholic and Benedictine cathedral. Coryat reported, "In this Church I saw many ancient monuments, as of Saint Luke the Evangelist, near to which is hanged up a fair table, wherein his Epitaph is written in Latin hexameter verses very elegantly". Coryat relates how with difficultly he reached through the iron grate to touch with his fingertips the iron coffin of Luke's bones that had been shipped there from Constantinople. Luke's remains, however, were removed nearby to a brass monument, again "sumptuous". Near the tomb Coryat observed an apothecary's room stocked with medicines for the poor and amazing crocodile skins. ${ }^{85}$

Balancing the rule of prayer, the commonest daily Benedictine labour, from Canterbury in England to Padua in Italy, was the collection, copying, and care of manuscripts. ${ }^{86}$ The motto Ora et labora on Harvey's title-page alludes critically to this work. In his school days at Canterbury no monks survived to transcribe a word. But at Padua the Benedictines of the abbey and cathedral of S. Giustina expanded their library, which included medical volumes. Its monks composed biblical and patristic scholarship of humanist inspiration.

Physicians, London. Jonathan Woolfson, Padua and the Tudors: English students in Italy, 1485-1603, University of Toronto Press, 1998, pp. 22-23.

${ }^{82}$ Alberta de Nicolò Salmazo, et al. (eds), I benedettini a Padova e nel territorio padovano atraverso I secoli, catologo di mostra Padua, 1980, Padua, Abbazia di s. Giustina, 1980, pp. 307-10; Alberta de Nicolò Salmazo, 'Le storie di san Luca e di san Mattia di Giovanni Storlato: dalla leggenda alla realtà', in Giovanni B Francesco Trolese (ed.), Riforma di chiesa, cultura e spiritualità nel quattrocento veneto, Cesena, Badia di s. Maria del Monte, 1984, pp. 443-65. Storlato's fresco of St Luke as a physician-evangelist is not extant in that chapel. I wish to thank Nadia Saracoglu for on-site confirmation of this in the summer of 2005. However, Mantenga also painted above the chapel's altar a polyptych of Luke at his desk writing the gospel.
See Giulio Bresciari Alvarez, 'La basilica di s. Giustina nelle sue fasi storico-costruttive', in Zovatto, et al. (eds), op. cit., note 79 above, pp. 97-110; Ivanoff, op. cit.. note 80 above. pp. 169-81, and 182 pl. 14; Salmazo, op. cit., note 80 above, pp. 63-66, 68-69, and between pp. 89-9 pl. I.

${ }^{83}$ For the seal, see Clark, Cook and Briggs, op. cit., note 69 above, vol. 1, p. 94.

${ }^{84}$ Robert Fludd, Mosaicall philosophy, London, Humphrey Moseley, 1659, p. i of preface, cited by Huffman, op. cit., note 37 above, p. 102.

${ }^{85}$ Coryat, op. cit., note 78 above, vol. 1, pp. 355 , 288, 290-2. For contemporary travelogues, see Fynes Moryson, An itinerary, 3 vols, Glasgow, James Maclehose and Sons, 1907, vol. 1, pp. 152-3; Francis Schott, Itinerarium Italiae rerumque romanarum, Antwerp, Plantiniana, 1600, p. 32.

${ }^{86}$ See Knowles, op. cit., note 66 above, p. 528. 


\section{Marjorie O'Rourke Boyle}

Distinctive to that Benedictine community was their theology of salvation as therapeutic, as the restoration of a broken human nature to its created divine image by the healing of Christ the physician. ${ }^{87}$ Together with the saying "commit to God", the title-page of Harvey's printed anatomy book supplants the monastic manuscript tradition with anatomical manual labour, like its heraldic angel with the rolled-up sleeves. In De motu cordis et sanguinis Harvey opposes with observation, demonstration, and reason toward truth the blinkered, untested, and mindless copying of truisms. His criticism targets the medical profession, which practised a secular version of monastic labour by the transmission of its own manuscript tradition as sacrosanct. Harvey's reform fundamentally challenges a norm of monastic, later humanist, imitiation that was misunderstood as correct, even holy, and canonized institutionally by the churches. As he notably proclaimed, he applied his mind "to observation" to invent his own book "from many dissections ... through autopsy, and not through books and the writings of others". ${ }^{8}$

Harvey's skilled rhetorical argument situates the anatomy of De motu cordis et sanguinis within the context of service to "the literary republic". With this very criterion, "useful to the literary republic", he emphatically concludes its epistle dedicatory to John Argent, president of the College of Physicians. And he defends the phrase "useful to the literary republic" in his first chapter. ${ }^{89}$ This cultural commitment persists to his last work, Exercitatio de generatione animalium of 1651, which his colleague and apologist George Ent introduces as Harvey's auspicious offering "to the literary republic". ${ }^{90}$ Harvey's formative education by royal statutes at the King's School, Canterbury, was humanist, in bonae litterae, "good letters". ${ }^{91}$ His related term res publica literaria is not classical but contemporary. It designates a cultural commonwealth that transcended nationalities and generations, a humanist mentality dedicated to scholarship in learned dialogue. It was a collaborative ideal grounded in the common usefulness of research, which expressed itself variously, from discussion groups to epistolary exchanges. The term originated in the Renaissance with Francesco Barbaro's congratulatory letter to Poggio Bracciolini for his discovery of the complete manuscript of Quintilian's Institutio oratoria. ${ }^{92}$ That very text formed the basis of the English grammar school curriculum for Harvey and

\footnotetext{
${ }^{87}$ See Collett, op. cit., note 77 above, pp. 8-261, $27,71$.

88 " Cvm multis viuorum dissectionibus (vti ad manum dabantur) animum ad obseruandum primum appuli; quo cordis motus vsum, et vtilitates in animalibus per autopsiam, et non per libros aliorumque scripta inuenirem". Harvey, op. cit., note 1 above, p. 20

89 “. . . rei litterariae vtile”, ibid., p. 9. “. . r reipub. literariae ex opera mea vtile", p. 21.

90 "Harveum nostrum Reipublicae literariae commodo, Vestrae omnium dignitati, et honori suo litasse". George Ent, Prefatory letter to William Harvey, Exercitationes de generatione animalium, London, Octavian Pulleyn, 1651, p. a4.

${ }^{91}$ See Leach, op. cit., note 14 above, p. 452.

${ }^{92}$ Marc Fumaroli, 'The republic of letters', Diogenes, 1988, 143: 129-52, pp. 134-8; idem, 'La
}

république des lettres redécouverte', in Marta Fattori (ed.), Il vocabolario della République des lettres: terminologia filosofica e storia della filosofia: problemi di metodo, Florence, Leo S Olschki, 1997, pp. 41-56, on pp. 44-5. See also Françoise Waquet, 'Qu'est-ce que la République des Lettres? Essai de sémantique historique', Bibliothèque de l'École de Chartes, 1989, 147: 473-502; Paul Dibon,

'Communication in the Respublica literaria of the 17th century', in idem, Regards sur la Hollande du siècle d'or, Naples, Vivarium, 1990, pp. 153-70. The association of the respublica literaria with a Florentine academy of Medici patronage needs updating, for it did not exist as such. See James Hankins, 'The myth of the Platonic academy of Florence', Renaiss. Q., 1991, 44: 429-75. 


\section{William Harvey's Anatomy Book and Literary Culture}

his colleagues. ${ }^{93}$ Although the College of Physicians, London, at Amen Corner was located in a neighbourhood of booksellers-publishers, ${ }^{94}$ Harvey's decision to publish De motu cordis et sanguinis at Frankfurt in Latin, rather than at London in English, reflects his commitment to communicate research "useful to the literary republic", that is, across borders and beyond institutions. Indeed, Harvey's reception abroad and by individuals was quicker, temporally and mentally, than in England. ${ }^{95}$

The leading citizen of the literary republic was Erasmus, whose books Harvey studied at Canterbury and Cambridge. This position was guaranteed Erasmus by his excellent and prodigious texts and by his European travels to promote its learned but serviceable ideal of scholarship. The term res publica litteraria figures significantly in his essay on the adage about his own scholarly industry, "the labours of Hercules", abbreviated there as litteraria re. As he stated, "In rebuilding the republic of letters one must display the spirit of a second Hercules, and no fear of weariness at the prospect of your own loss should discourage you from serving the common good". ${ }^{96}$ Harvey probably also knew res publica litteraria from Erasmus's manual on a humanist education based in classical pronunciation. In that engaging dialogue, De recta pronuntatione, the characters, Lion and Bear, wisely discuss the proper education of cubs. Lion appoints Bear to the task: "By the authority vested in me by the Muses I herewith appoint thee dictator of studies and charge thee to protect against all harm the republic of letters". Lion's pedagogical premise is that he has "learnt from Galen that what differentiates man from the other animals, or brutes as they are called, is not reason, but speech". In the curriculum of his literary republic "medicine will only be included to the extent that knowledge of it helps to preserve health". ${ }^{97}$ However, that dictum pertains to the education of cubs (boys), not adult physicians-in-training. Lion's acknowledgement of Galen, rather than more obviously Quintilian, ${ }^{98}$ for the primacy of speech as normatively human couches a criticism. By citing Galen's exhortation to the study of medicine, whose text he had recently corrected and translated, Erasmus implicates the scholars of the Aldine edition of Galen in philological failure. For, the term res publica litteraria is salient there: it opens the preface to its very first volume. ${ }^{99}$ Erasmus thus allusively accuses Galen's editors of not measuring up to Galen's own standard of speech as definitively human.

\footnotetext{
${ }^{93}$ See Thomas W Baldwin, William Shakespere's small Latine and lesse Greeke, 2 vols, Urbana,

University of Illinois Press, 1944, vol. 2, pp. 197-238.

${ }^{94}$ Clark, Cook and Briggs, op. cit., note 69 above, vol. 1, p. 186.

${ }^{95}$ See recently French, op. cit., note 24 above, pp. 114-285

96 ،. . . oportet in restituenda literaria re animum Herculanum praestare, hoc est nullo tuo incommodo a communi vtilitate curanda vel deterrari vel defatigari". Erasmus, Adagia, ed. M L van Poll-van de Lisdonk, et al., in Opera omnia, Amsterdam, NorthHolland, 1969- , II-5, p. 39; R A B Mynors (trans.), The collected works of Erasmus, University of Toronto Press, 1971-, vol. 34, p. 81. See also, in general, Fritz Schalk, 'Erasmus und die "Res publica literaria", in Cornelis Reedijk (ed.), Actes du congrès Erasme, Rotterdam 27-29 octobre 1969, Amsterdam,
}

North-Holland, 1971, pp. 14-28; Fumaroli, 'République des lettres rédecouverte', op. cit., note 92 above, pp. 49-51.

97 "Creamus te Musis fauentibus studiorum dictatorem; cura ne quid respublica litteraria capiat detrimenti". "Quia Galenus me docuit, hominem a caeteris animantibus, quae vocamus aloga, discerni non ratione sed oratione". "Medicinae tantum addetur, quantum tuendae valetudine sat erit". Erasmus, De recta pronuntiatione, op. cit., note 18 above, pp. 18, 14, 31; Maurice Pope (trans.), Collected works of Erasmus, University of Toronto Press, 1974-, vol. 26 , pp. $372,369,387$

${ }^{98}$ See Quintilian, Institutio oratoria 2.16 .12 .

${ }^{99}$ Prefaces to the first editions of the Greek and Roman classics and of the Sacred Scriptures, Beriah Botfield (ed.), London, H G Bohn, 1861, p. 352. 


\section{Marjorie O'Rourke Boyle}

Aldine publications had, from the beginning of that Venetian press, issued epistolary prefaces addressed to students and lovers of good letters (bonae litterae). The press boasted of the academy it assembled for the critical supervision of the texts it published. It praised Thomas Linacre, soon to be founder of the College of Physicians, London, for establishing the texts for a collection of Greek astronomers. Three years later in 1502 the Aldine press institutionalized its academic concept into "the republic of letters". This ideal, coined by a Venetian, Barbaro, and published by a Venetian, Manutius Aldus, ${ }^{100}$ was proximate to Padua — only twenty-five miles distant—where Harvey studied arts and medicine at the university. Harvey's commendation of his De motu cordis et sanguinis as "useful to the literary republic" inserts his anatomy into this tradition, but subversively so. His motive rejects the imitation or emulation of the best classical authors that defined Renaissance humanism. Erasmus had only improved Galen's medicine textually. Harvey would better them both by anatomizing the literary republic into irrelevance for medicine. As he famously declared in his epistle dedicatory to the College, his medical foundation was not established on books. "I did not wish to show off midnight toils, heavy reading, and a large volume, in naming anatomical authors and writers, in reviewing works and judgments, in scouring my memory. So I set out to learn and to teach anatomy not from books, but from dissections, not from the opinions of philosophers, but from the fabric of nature". ${ }^{101}$ His text intends to be "useful to the literary republic" as a methodological correction of its culture as inapposite to medicine. Of pointed reference, the funeral oration for Harvey's anatomy professor at Padua, Girolamo Fabrici d'Aquapendente, had praised him with a litany of epithets that climaxed in "yes indeed, the common good of the universal literary republic". ${ }^{102}$ There is no record of Harvey's presence among the civic and academic dignitaries on that solemn occasion in 1619, which marked the burial of his renowned professor in an unmarked grave. Yet, the personification of Fabrici as "the common good of the universal literary republic" is a role Harvey aspires to reprise with a reform of that republic in which traditional books are no longer prescriptive for medicine. The humanist ideal of a learned exchange is retained; but its medium becomes anatomical, rather than literary, the shared recognition of "ocular demonstrations". As such, his anatomy book becomes a reasoned record of those demonstrations,

\footnotetext{
${ }^{100}$ Fumaroli, 'Republic of Letters', pp. 147-9; Fumaroli, 'République des lettres redécouverte', pp. 46-8, 52, both cited in note 92 above. See also Fumaroli, 'Venise et la République des Lettres au XVIe siècle', in Vittore Branca and Carlo Ossola (eds), Crisi e rinnovamenti nell' autunno del Rinascimento a Venezia, Florence, Leo S Olschki, 1991, pp. 343-57.

101 “... in authorum et scriptorum Anatomicorum nominibus, operibus et sententiis recensendis, exagitandis memoriam meam, et lucubrationes, multamque lectionem et magnum volumen ostentare nolebam. Tum quod non ex libris, sed ex dissectionibus, non ex placitis Philosophorum, sed
}

fabrica naturae discere et docere Anatomen profitear". Harvey, op. cit., note 1 above, p. 8 .

102 “. . . imo universae rei litterariae commune bonum". Joannes Thuilius, Funus perillustris ..., cited by Kenneth J Franklin's introduction to Fabrici d'Acquapendente, De venarum ostiolis (1603), facsimile rpt., London, Baillière, Tindall and Cox, 1933, p. 13. For humanist influence on medicine at Padua, see Jerome J Bylebyl, 'The school of Padua: humanistic medicine in the sixteenth century', in Charles Webster (ed.), Health, medicine and mortality in the sixteenth century, Cambridge University Press, 1979, pp. 335-70. 
rather than an imitation, or even emulation, of literary texts. Thus is ruined the classical ideal. $^{103}$

Although Harvey's book was received on the continent, ${ }^{104}$ it was not welcomed in its republic of letters. In the decade following its publication, for example, Théophraste Renaudot convened at Paris the Bureau d'Adresse for intellectual exchange. But its public conferences on medicine, later published, most frequently referred to Hippocrates and Galen, with humoral theory prevailing. More recent theory, such as Harvey's on the circulation of the blood, seemed upstart to the numerous physicians "chez Renaudot". 105 And although the res publica litteraria acquired the vernacular synonym République des sciences $^{106}$ that designated, from the Latin scientia, a community of learning, not of science. Despite Harvey's move from his anatomy table to his writing desk, his contribution intended to be "useful to the literary republic" did not insert De motu cordis et sanguinis into its humanist tradition. As an anatomy book, it rejected its literary culture.

${ }^{103}$ For its reception, see Thomas M Greene, The light in Troy: imitation and discovery in Renaissance poetry, New Haven, CT, Yale University Press, 1982; George W Pigman III, 'Versions of imitation in the Renaissance', Renaiss. Q., 1980, 33: 1-32. For the foundations of emulation, which is Erasmus's theory, see Marjorie O'Rourke Boyle, Erasmus on language and method in theology, University of Toronto Press, 1977, pp 3-57.

\footnotetext{
${ }^{104}$ French, op. cit., note 24 above, pp. 150-285.

${ }^{105}$ Simone Mazauric, 'La diffusion du savoir en dehors des circuits savants: le bureau d'adresse de Théophraste Renaudot', in Hans Bols and Françoise Waquet (eds), Commercium litterarium: la communication dans la République des Lettres, 1600-1750, Amsterdam, APA-Holland University Press, 1994, pp. 229-58, on pp. 168-9.

${ }^{106}$ Waquet, op. cit., note 92 above, p. 478.
} 